\title{
Evaluation of mining companies based on benchmarking
}

\author{
Michal VAN KKK $^{1 *}$, Igor ČERNÝ ${ }^{2}$, Vlastimil HUDEČEK ${ }^{3}$, Tomáš KUBICA ${ }^{4}$ and \\ Verroslav HOLUS̆A
}

\begin{abstract}
Authors' affiliations and addresses:
${ }^{1}$ VŠB - Technical University of Ostrava, Faculty

of Mining and Geology, Department of

Economics and Control Systems, 17. listopadu

2172/15, 70800 Ostrava, Czech Republic

e-mail: michal.vanek@vsb.cz

${ }^{2}$ VŠB - Technical University of Ostrava, Faculty of Mining and Geology, Department of Economics and Control Systems, 17. listopadu 2172/15, 70800 Ostrava, Czech Republic e-mail: igor.cerny@vsb.cz

${ }^{3}$ VŠB - Technical University of Ostrava, Faculty of Mining and Geology, Department of Mining Engineering and Safety, 17. listopadu 2172/15, 70800 Ostrava, Czech Republic

e-mail: vlastimil.hudecek@vsb.cz

${ }^{4}$ VŠB - Technical University of Ostrava, Faculty of Mining and Geology, Department of Economics and Control Systems, 17. listopadu 2172/15, 70800 Ostrava, Czech Republic e-mail: tomas.kubica@vsb.cz

${ }^{5}$ VŠB - Technical University of Ostrava, Faculty of Mining and Geology, Department of Economics and Control Systems, 17. listopadu 2172/15, 70800 Ostrava, Czech Republic e-mail: veroslav.holusa@vsb.cz

*Correspondence:

Michal Vaněk, VŠB - Technical University of Ostrava, Faculty of Mining and Geology,

Department of Economics and Control systems, 17. listopadu 2172/15, 70800 Ostrava, Czech Republic

tel.: +420 596993336

e-mail: michal.vanek@vsb.cz
\end{abstract}

How to cite this article:

Vaněk, M., Černý, I., Hudeček, V., Kubica, T. and Holuša, V. (2021). Evaluation of mining companies based on benchmarking, Acta Montanistica Slovaca, Volume 26 (4), 732-747.

DOI:

https://doi.org/10.46544/AMS.v26i4.11

\begin{abstract}
Managerial and investment decision quality is influenced, inter alia, by the availability of high-quality information. The sources of such information may be different analyses and studies, including company benchmarking. However, such analyses and studies often have in-company character, which makes access to some information on the national economy difficult. To deal with this problem in the mining sector, the article deals with benchmarking of 30 mining companies operating in the Czech Republic. Based on the size of mining, the first four companies in each group of minerals, or more precisely, a subgroup of minerals (hard coal, brown coal, oil, natural gas, brick raw material, building stone, decorative stone, gravel and sand, limestone, kaolin, clays and bentonite) were selected for the benchmarking project. Benchmarking was conducted for the period from 2011 to 2018 using six financial analysis indicators: ROA, inventory turnover, total debt, immediate liquidity, LTTA productivity, networking capital turnover. Individual benchmarks do not have the same weight, and weights were determined by AHP. The evaluation was done using a mathematical-statistical method of the weighted sum approach. The benchmarking showed that the top 3 mining companies are Cement Hranice, akciová společnost (1) limestone; Green Gas DPB, a.s. (2) - energy raw materials (natural gas); and EUROVIA Kamenolomy, a.s. (3) - building materials (building stone). At the opposite end of the list there are: Cihelna Hodonín, s.r.o. (30) - building materials (brick-making material); Sedlecký kaolin, a.s. (29) - kaolin; and CEMEX Sand, k.s. (28) building materials (gravel and sand). Furthermore, it was found that: (i) the economic success of the mining undertaking is not related to the volume of production or indebtedness; (ii) limited liability companies are more economically successful than joint-stock companies. It has not been proven unequivocally that specialisation in a single extracted material is a better strategy than extracting more mineral resources.
\end{abstract}

\section{Keywords}

Benchmarking; mining company; mineral resources of the Czech Republic; ratios of financial analysis. 


\section{Introduction}

In many countries, local deposits of mineral resources are the key resources through which countries provide for their economies. Therefore, countries cannot do away with enterprises that extract mineral resources and process them further to satisfy the needs of the growing population. As Arnold et al. (2009) perceive it, all semifinished products are made from raw materials, and the demand on the part of customers and raw material markets thus form the interfaces of supply chains. In other words, supply chains ending with a customer start with raw materials (Lambert and Cooper, 2000). The interconnectedness of the different supply chain segments influences, inter alia, the end costs of products, which increases the natural pressure on companies' efficiency and economy.

However, extraction and processing of mineral resources are branches of the industry with a number of specificities and unique features (Laciak, 2013). Moreover, besides market threats, companies in the mining industry face many forms of operational risks, such as changing government policies, environmental incidents, and other circumstances affecting the survival of the enterprise on the market (Van Thuyet et al., 2007).

A standard for public reports, which include information that is given to investors, potential investors and professional advisers about exploration results, mineral resources and mineral reserves the "Pan-European Standard for Reporting of Exploration Results, Mineral Resources and Reserves" (Krzemień et al., 2016).

One of the managers' imperative, including mining company managers, is to seek and maintain the competitive advantage of the companies they manage. The competitive advantages are difficult to obtain, especially in the existing turbulent market conditions (Kotler, 2006). To succeed under difficult conditions, managers need to have knowledge and skills but also need relevant competencies, inner motivation for success, and the capacity of self-reflection to be able to learn from mistakes. It is also important to have various managerial tools, methods and techniques. One of these is benchmarking, which continuously and systematically helps companies to improve (Karlöf et al., 1993).

One of the key attributes of benchmarking are the very benchmarks that are used for comparisons. Correctly selected benchmarks assess the company's value. According to Zairi (2017), metrics are short-term measures that are continually calculated and reviewed. Metrics can represent (i) financial performance indicators (business performance); (ii) technical performance indicators (productivity measurement); and (iii) performance indicators (human contribution measurement).

Thanks to benchmarking, company management may obtain valuable information on their company's position among the competitors, and it is the ordering party who decides whether the benchmarking results will be made available inside the company or to all parties interested. In the case of long-term benchmarking, managers can see the development of a particular company and of their competitors. Benchmarking may help identify areas in which the company lags behind or in which the company outperforms others. It is thus an indispensable tool in keeping competitive advantages. Moreover, for managers, the findings obtained from benchmarking may be valuable in order to improve the existing products and processes but also to obtain useful tips when investing in new acquisitions.

We were not surprised when doing this research that the topic of benchmarking had been reported in many studies. Taking Web of Science as a reference database, the keyword "benchmarking" offered 245 thousand records. However, we were quite surprised that using keywords related to this research, the search rendered only 32 records. For example, Fordham (2004) benchmarked 17 mining companies to understand the problems that companies face, the methods being used to improve performance, and the results achieved. Hall (2005) focused on benchmarking as a technique to measure and improve operational performance in underground mines. Tsolas (2008) presented the use of a non-parametric approach (i.e., data envelopment analysis, DEA) for the development of environmental sustainability indicators in mineral processing using environmental, economic and/or integrated indicators. More recently, Ming et al. (2012) studied mining enterprise performance management systems. Vaněk et al. (2013) reported benchmarking results of major limestone producers in the Czech Republic, and in 2017 Vaněk et al. presented the results of a project benchmarking mining companies extracting black coal in the UpperSilesian Basin. Pan et al. (2014) focused on studying the relationship between CSR and CFP in the Chinese mineral industry using the panel data of 228 listed mineral firms from 2010 to 2013 with Pooled Least Squares regression analysis. Kazanin (2016) dealt with benchmarking initiatives in the field of occupational safety and health in the context of the development of the coal industry of Russia. Černý et al. (2019) considered the mutual replaceability of mathematical-statistical methods used for evaluation in benchmarking and verified the agreement in results rendered by the solvency and bankruptcy models and those rendered by mathematical-statistical methods.

The literature review implies that in the conditions of the Czech Republic, the benchmarking of mining companies is studied in the long-term by a team of authors with the Department of Economics and Raw Material Control at the Faculty of Mining and Geology, but the studies deal with the extraction of black coal and limestone only. We could not find any comprehensive studies that would deal with mining companies, which are likely to exist for in-company use only.

What is also missing is a comprehensive study of the raw material sector in the conditions of the Czech Republic, which would be available to a wide public. We claim that both scholars and future investors would 
benefit from the conclusions of such a benchmarking project. Similarly, such a benchmarking project may serve as an inspiration for analogous benchmarking projects in other countries to provide valuable information on the state and development of mining companies worldwide. Such information would be valuable, especially for foreign investors who may obtain supportive documentation for investment decision-making.

In the Czech lands, mining and processing of minerals were among the most important sectors that contributed decisively to the performance of its economy. However, the current reality is different. According to data from the Czech Statistical Office, in 2018, the mining sector accounted for $0.52 \%$ of total output at current prices, according to CZ-NACE. According to the latest yearbook Raw Materials of the Czech Republic published in 2018, 232 enterprises were engaged in mining and processing of minerals.

Since these companies are in many ways incomparable (e.g., mining size, capital size, turnover, number of raw materials extracted, number of employees), we decided to focus our benchmarking project only on important companies in individual groups or subgroups of minerals according to the technical-economic classification of raw materials. Specifically, these were the companies exploiting building stone, gravel and sand, decorative stone, brick raw material, limestone, clays and bentonites and lignite. Thus, the project did not include enterprises focusing on less important raw materials in terms of mining volume (e.g., dolomite, gypsum, moldavite, spongylite, and wollastonite). In the raw material portfolio of our benchmarking project, ores are not included because they are not currently mined in the Czech Republic.

The following hypotheses constitute the basis of the research:

(H1) As the production volume increases, the economic success of the mining undertaking as expressed by the value of the rating increases.

(H2) Mining companies specialising in the extraction of a single mineral are more economically successful.

(H3) The low indebtedness of the mining undertaking results in the economic success of the mining undertaking as expressed in the value of the evaluation number.

(H4) Joint-stock companies are more economically successful than limited liability companies.

Apart from confirming or refuting the above hypotheses, the article aims to identify the best mining company across the spectrum of mineral resources extracted in the Czech Republic using financial analysis indicators.

\section{Material and Methods}

Benchmarking is about comparing processes, practices or procedures. There are several ways to classify types of benchmarking, depending on the focus of the benchmarking process. Types of benchmarking are (1) Performance benchmarking, (2) Process benchmarking, (3) Strategic benchmarking, (4) Internal benchmarking, (5) Competitive benchmarking, (6) Functional benchmarking, and (7) Generic benchmarking (Ifeoluwa, 2010).

The comparison is made in the same market to compare performance and results and identify the "best" competition. Our benchmarking project is of a competitive benchmarking type.

Although there are a number of theories behind benchmarking, experience shows that a benchmarking technique is usually reduced to determining the number of consecutive steps that should lead to the desired result. The number of steps differs as different processes can be broken down into substeps. For example, IBM has a 15stage model; other companies may have fewer stages (Goncharuk, 2015).

The nature and purpose of the intended benchmarking predetermined that the authors focused on the field of performance from an external perspective. When implementing the benchmarking itself, the authors proceeded according to the Xerox benchmarking model, which consists of ten steps summarised in Tab. 1.

Tab. 1. Basic stages of benchmarking (modified according to Cross, 1995)

\begin{tabular}{|c|ll|}
\hline Benchmarking stage & \multicolumn{2}{|c|}{ Basic steps } \\
\hline \multirow{3}{*}{ Planning } & 1. & Benchmarking object identification \\
& 2. & Identification of benchmarking partners \\
& 3. & Selection of data collection method \\
& 4. & Data Collection \\
\hline \multirow{2}{*}{ Analysis } & 5. & Data evaluation \\
& 6. & Defining the future level of self-performance \\
\hline \multirow{2}{*}{ Integration } & 7. & Data evaluation \\
\hline \multirow{2}{*}{ Realisation } & 8. & Planning of improvement goals \\
\hline
\end{tabular}

The first and the second stage are decisive for the fulfilment of the goals of our article, and therefore these stages became the basis for the benchmarking itself.

As data collection from publicly available sources was assumed, financial ratios were selected as benchmark objects, with one representative per area of financial analysis: (X1) Profitability Indicators - ROA; (X2) Activity 
indicators - inventory turnover ratio; (X3) Debt indicators - debt ratio; (X4) Liquidity ratios - cash ratio; (X5) Operational indicators - Productivity of Long-Term Tangible assets; (X6) Financial fund and cash flow indicators - Net Working Capital turnover ratio.

The use of traditional economic evaluation methods by techniques of investment and financial analysis is well adopted in mining evaluation (Čech, 2018). Brigham (2014) defines financial ratios as designed to extract significant data that need not be clear from the financial reports. Brealey (2018) suggests that financial ratios are "no substitute for a crystal ball", but rather a useful design for high amounts of financial data that may be summarised and company performance contrasted.

The following is a series of relationships used to calculate the selected indicators. The following formulas also show the inputs needed for the calculation itself.

$$
\begin{aligned}
& \text { ROA }=\frac{\text { EBIT }}{\text { assets }} * 100 \\
& \text { Inventory turnover ratio }=\frac{\text { annual sales }}{\text { inventory }} \\
& \text { Debt ratio }=\frac{\text { foreign capital }}{\text { assets }} * 100 \\
& \text { Cash ratio }=\frac{\text { cash }}{\text { immediately payable liabilities }} \\
& \text { Productivity of Long }- \text { Term Tangible Assets }=\frac{\text { annual sales }}{\text { tangible assets }} \\
& \text { Net Working Capital turnover ratio }=\frac{\text { net working capital } * 365}{\text { annual sales }}
\end{aligned}
$$

The indicators were selected based on the discussion of the authors of the article. The choice of the above indicators can be justified as follows. Profitability is one of the most important ratios because it expresses the ability of the property to generate profit. Of all profitability ratios, ROA is the most important one, as it comprehensively appreciates total assets without the impact of their funding sources. Inventory turnover is an indicator of the overall activity of the company. As stocks are capital-bound and are the least liquid current asset, due consideration must be given to them.

The indicator Debt ratio was chosen because it provides information on the company's long-term financial stability. The Cash ratio measures the ability of a company to pay its debts and has therefore been included as a benchmark. Long-Term Tangible Assets (LTTA) form a significant part of fixed costs in the form of depreciation, and it is therefore necessary to include them. The Productivity of LTTA expresses the degree of its utilisation. Turnover time of Net Working Capital expresses the ability of the company to work effectively with freely available means, and therefore this indicator was chosen.

As the benchmarking project focused on significant companies operating within individual raw material subgroups, a criterion for the inclusion of the company in the project was necessary. This criterion was the size of mining within the individual subgroups listed in the Mining Yearbook 2017. The reason why 2017 became the reference year is the fact that the Mining Yearbook 2018 no longer includes the mining volumes of enterprises.

The first four enterprises of each raw material subgroup were included in the benchmarking project according to this criterion. In case the mining company operates in several raw material subgroups, it is only presented once in the overall overview. An overview of the mining companies included in the benchmarking project is given in Tab. 3.

The mining enterprises are introduced with the legal form of valid Czech legislation. English equivalents are presented in Tab. 11.

The source of the benchmarking data were the basic financial statements of selected mining companies, which were obtained from the Public Register and the Collection of Documents (https://or.justice.cz/ias/ui/rejstrik).

If benchmarking data were only based on data from one year, the result would not be sufficiently objective. Therefore, the reference period 2011-2018 was chosen.

A basic dataset containing relevant data from the underlying financial statements of benchmarked mining companies is available at https://data.mendeley.com/drafts/7h6wkxs5vv.

Trends of the mining volume of selected enterprises in the reference period are shown in Appendix A. Appendix A is based on data from the Mining Yearbook of the reference period $2011-2018$.

A number of specific methods may be used for benchmarking comparisons. The essence of benchmarking is most similar to the "Method of Weighted Sum Approach" (Anderson et al., 1994). 
The Weighted Sum Approach (WSA) method works on the principle of maximising the use, i.e. it organises variants in order of overall performance, which takes into account all the criteria represented. The value of the variant's performance is in the range $\langle 0,1\rangle$, and the more appropriate the variant is according to each criterion, the higher its value. The total benefit of 1 would be the option that is best according to all criteria. The calculation procedure is implemented in two steps (Anderson et al., 1994):

1) The normalisation of input data - The aim of this step is to cancel out the influence of different units and different sizes of numeric scales. Normalisation values range on the $\langle 0-1\rangle$ scale for each criterion and indicate the percentage of the maximum or minimum value (depending on the type of criterion that can be either maximised, i.e. preferring higher values or minimised with a lower value preference). The WSA method uses a formula for maximising type criteria:

$$
r_{i j}=\frac{y_{i j}-B_{j}}{I_{j}-B_{j}}
$$

For criteria of the minimisation type, the formula is:

$$
r_{i j}=\frac{I_{j}-y_{i j}}{I_{j}-B_{j}}
$$

Where:
i variant index,
j criteria index,
$y_{i j} \quad$ original value of variant $i$ according to criterion $j$,
$I_{j} \quad$ ideal variant consisting of maximum values according to each criterion,
$B_{j} \quad$ basal variant consisting of minimum values according to each criterion.

The variant that is best according to the given criterion achieves partial benefit $r_{i j}=1$, the worst variant of partial benefit $r_{i j}=0$.

2) Calculation of the total benefit - The total benefit of $u_{i j}$ is obtained by multiplying the partial benefits $r_{i j}$ by the weights of the individual criteria and the subsequent sum, i.e. from the formula:

$$
u\left(a_{i}\right)=\sum_{j=1}^{k} r_{i j} \cdot w_{j}
$$

Where:

$\begin{array}{ll}u\left(a_{i}\right) & \text { overall benefit of the } \mathrm{a}_{\mathrm{i}} \text { variant, } \\ r_{i j} & \text { normalised values from the previous step (partial benefits) } \\ w_{j} & \text { weight of the } j \text {-th criterion, } \\ k & \text { number of criteria. }\end{array}$

The benchmarking information value can be increased if the ratios of comparison are weighted. This can be done in many ways. The authors decided to use AHP to determine the weights. The reason is that unlike the method of pairwise comparison, where one criterion from the pair is simply preferred, also the magnitude of this preference is specified. The magnitude is expressed by a number of points from a predetermined scale, according to Saaty (2001).

Each benchmark pair is assigned according to the Saaty preference scale:

(1 - equivalence, 3 - weak preference, 5 - strong preference, 7 - very strong preference,

9 - absolute preference). The result is then the Saaty matrix, which is the starting point for the actual determination of the weights, Figure 1.

$$
\begin{aligned}
& \qquad S=\left(\begin{array}{cccc}
1 & s_{12} & \ldots & s_{1 n} \\
1 / s_{12} & 1 & \ldots & s_{2 n} \\
\ldots & \ldots & \ldots & \ldots \\
1 / s_{1 k} & 1 / s_{12} & \ldots & 1
\end{array}\right) . \\
& \text { Fig. 1. Saaty's matrix } \\
& \text { Source: Saaty (2001) }
\end{aligned}
$$

The actual weight values of criteria are determined using geometric means of the rows of the Saaty's matrix, which are then normalised by the equation (10). 


$$
v_{i}=\frac{G_{i}}{\sum_{i=1}^{n} G_{i}}
$$

Where:

$v_{i} \quad$ normalised weight of the $i$-th criterion,

$G_{i} \quad$ geometric mean of the $i$-th criterion,

$n \quad$ number of criteria (Saaty, 2008).

The preferences of individual benchmarks are determined based on the authors' brainstorming. In accordance with the AHP methodology, a consistency indicator is also calculated, which should be less than 0.1 .

The application of the procedure mentioned above enables a comparison of mining companies in the different years. However, it does not offer an overall conclusion on the efficiency of the discrete mining companies. This may be answered by a value number $(V N)$ assessing each of the four mining companies between 2011 and 2018. $V N$ is obtained by means of the formula below (11):

$$
V N=\sum_{i=1}^{n} u\left(a_{i}\right)
$$

Where:

$u\left(a_{i}\right) \quad$ overall benefit calculated as weighted arithmetic mean by use of standard variables,

$n \quad$ total number of benchmarking mining enterprises.

Validity of the hypotheses $\mathrm{H} 1$ and $\mathrm{H} 3$ is evaluated using correlation analysis of mining enterprise ranking according to a value number and ranking of mining enterprises according to mining volume or ranking of mining enterprises according to debt ratio. Correlation analysis was carried out using the MS EXCEL CORELL function (matrix1; matrix2). The validity of the hypotheses $\mathrm{H} 2$ and $\mathrm{H} 4$ is determined via relative frequency.

\section{Results}

In order to create initial matrices, it is necessary to determine their weights in addition to the ratio indicators. Tab. 2 shows the preference of benchmarks and their weights. The same benchmark weights are used for all years of the period 2011-2018.

\begin{tabular}{|c|c|c|c|c|c|c|c|c|}
\hline Criterion & $\mathrm{X} 1$ & $\mathrm{X} 2$ & $\mathrm{X} 3$ & $\mathrm{X} 4$ & $\mathrm{X} 5$ & X6 & $\begin{array}{c}\text { Geometric } \\
\text { average }\end{array}$ & Standardised weight \\
\hline $\mathrm{X} 1$ - ROA & 1 & 9 & 5 & 7 & 5 & 7 & 4.7177 & 0.5165 \\
\hline $\mathrm{X} 2$ - Inventory turnover ratio & $1 / 9$ & 1 & $1 / 5$ & 1 & $1 / 3$ & 1 & 0.4415 & 0.0483 \\
\hline X3 - Debt ratio & $1 / 5$ & 5 & 1 & 3 & 3 & 5 & 1.8860 & 0.2065 \\
\hline $\mathrm{X} 4-$ Cash ratio & $1 / 7$ & 1 & $1 / 3$ & 1 & $1 / 3$ & 3 & 0.6020 & 0.0659 \\
\hline X5 - Productivity of LTTA & $1 / 5$ & 3 & $1 / 3$ & 3 & 1 & 3 & 1.1029 & 0.1208 \\
\hline X6 - NWC turnover ratio & $1 / 7$ & 1 & $1 / 5$ & $1 / 3$ & $1 / 3$ & 1 & 0.3834 & 0.0420 \\
\hline SUM & & & & & & & 9.1335 & 1 \\
\hline
\end{tabular}

Tab. 2. Determination of weights using Saaty's method

The Consistency ratio was 0.09 , which means that the matrix is consistent and, therefore, we can work with the calculated weights.

After the weights were determined, the starting matrices for the individual years of the period considered could be completed. Tab. 3 shows the values of the default matrix for the year 2011 and Tab. 4 for 2018. All starting matrices are then made available at https://data.mendeley.com/drafts/7h6wkxs5vv.

\begin{tabular}{|c|c|c|c|c|c|c|}
\hline Mining Enterprise & X1 - ROA & $\begin{array}{l}\mathrm{X} 2 \text { - Inventory } \\
\text { Turnover ratio }\end{array}$ & $\begin{array}{c}\text { X3 - Debt } \\
\text { ratio } \\
\end{array}$ & X4 - Cash ratio & $\begin{array}{c}\text { X5 - Productivity } \\
\text { of LTTA }\end{array}$ & $\begin{array}{c}\text { X6 - NWC turnover } \\
\text { ratio } \\
\end{array}$ \\
\hline KERACLAY, a.s. & $0.00 \%$ & 0.00 & $10.86 \%$ & 0.01 & 0.00 & - \\
\hline LB MINERALS, s.r.o. & $5.45 \%$ & 18.41 & $45.04 \%$ & 0.50 & 0.82 & 47.76 \\
\hline Sedlecký kaolin a. s. & $0.33 \%$ & 4.50 & $47.26 \%$ & 0.19 & 0.98 & 134.79 \\
\hline KERAMOST, a.s. & $2.89 \%$ & 18.06 & $69.57 \%$ & 0.92 & 4.03 & 76.36 \\
\hline Kaolin Hlubany, a.s. & $7.64 \%$ & 86.23 & $19.17 \%$ & 0.50 & 1.15 & 465.95 \\
\hline Granit Lipnice, s.r.o. & $2.30 \%$ & 5.81 & $25.74 \%$ & 0.63 & 3.76 & 109.44 \\
\hline HERLIN spol. s.r.o. & $1.93 \%$ & 6.14 & $55.81 \%$ & 0.28 & 2.60 & 18.98 \\
\hline
\end{tabular}

Tab. 3. Starting matrix in 2011 


\begin{tabular}{|c|c|c|c|c|c|c|}
\hline Plzeňská žula a.s. & $-4.30 \%$ & 8.91 & $31.99 \%$ & 0.38 & 2.91 & - \\
\hline Průmysl kamene a.s. & $2.99 \%$ & 5.48 & $8.51 \%$ & 3.00 & 0.92 & 186.64 \\
\hline CEMEX Sand, k.s. & $5.63 \%$ & 13.61 & $80.34 \%$ & 0.07 & 1.19 & 82.77 \\
\hline $\begin{array}{c}\begin{array}{c}\text { České štěrkopísky spol. s } \\
\text { r.o. }\end{array} \\
\end{array}$ & $8.70 \%$ & 0.00 & $59.73 \%$ & 0.04 & 1.01 & - \\
\hline Českomoravský štěrk, a.s. & $5.44 \%$ & 7.22 & $30.83 \%$ & 0.25 & 1.31 & 128.57 \\
\hline $\begin{array}{c}\text { EUROVIA Kamenolomy, } \\
\text { a.s. } \\
\end{array}$ & $3.08 \%$ & 23.36 & $15.78 \%$ & 0.63 & 1.67 & 149.35 \\
\hline KÁMEN Zbraslav, a.s. & $5.84 \%$ & 51.82 & $45.36 \%$ & 3.13 & 1.71 & 533.41 \\
\hline $\begin{array}{l}\text { KAMENOLOMY ČR } \\
\text { s.r.o. }\end{array}$ & $12.85 \%$ & 10.66 & $33.28 \%$ & 0.21 & 1.27 & 43.33 \\
\hline $\begin{array}{c}\text { HELUZ cihlářský průmysl } \\
\text { v.o.s. } \\
\end{array}$ & $3.18 \%$ & 71.21 & $5.47 \%$ & 0.20 & 0.67 & 100.34 \\
\hline Wienerberger s.r.o. & $7.13 \%$ & 18.39 & $57.59 \%$ & 0.30 & 1.83 & 26.83 \\
\hline Cihelna Hodonín, s.r.o. & $-10.25 \%$ & 13.58 & $145.01 \%$ & 0.01 & 0.33 & - \\
\hline Severočeské doly a.s. & $18.82 \%$ & 14.76 & $27.07 \%$ & 0.26 & 0.54 & 67.32 \\
\hline $\begin{array}{c}\text { Sokolovská uhelná, právní } \\
\text { nástupce, a.s. }\end{array}$ & $7.31 \%$ & 22.31 & $29.92 \%$ & 5.60 & 0.92 & 382.94 \\
\hline Vršanská uhelná a.s. & $4.12 \%$ & 257.26 & $30.74 \%$ & 6.94 & 0.24 & 52.08 \\
\hline Severní energetická a.s. & $9.25 \%$ & 955.78 & $69.26 \%$ & 0.63 & 0.76 & 1912.35 \\
\hline Green Gas DPB, a.s. & $19.04 \%$ & 116.26 & $75.09 \%$ & 1.18 & 1.64 & 197.51 \\
\hline MND a.s. & $5.49 \%$ & 2.74 & $31.00 \%$ & 2.45 & 0.50 & 398.18 \\
\hline LAMA GAS \& OIL s.r.o. & $35.45 \%$ & 265.09 & $9.99 \%$ & 0.42 & 0.78 & 64.85 \\
\hline OKD, a.s. & $17.40 \%$ & 37.04 & $49.17 \%$ & 0.27 & 1.35 & 53.23 \\
\hline $\begin{array}{l}\text { Českomoravský cement, } \\
\text { a.s. }\end{array}$ & $13.25 \%$ & 11.24 & $26.77 \%$ & 0.03 & 1.03 & 184.41 \\
\hline $\begin{array}{l}\text { Velkolom Čertovy schody, } \\
\text { akciová společnost }\end{array}$ & $0.75 \%$ & 87.94 & $19.92 \%$ & 1.58 & 0.79 & 287.13 \\
\hline $\begin{array}{l}\text { KOTOUČ ŠTRAMBERK, } \\
\text { spol. s r. o. }\end{array}$ & $8.39 \%$ & 11.12 & $27.52 \%$ & 0.44 & 1.52 & 123.67 \\
\hline $\begin{array}{c}\text { Cement Hranice, akciová } \\
\text { společnost }\end{array}$ & $28.58 \%$ & 11.00 & $20.13 \%$ & 0.58 & 1.68 & 175.04 \\
\hline Weight & $51.65 \%$ & $4.83 \%$ & $20.65 \%$ & $6.59 \%$ & $12.08 \%$ & $4.20 \%$ \\
\hline Character of indicator & 1 & 1 & -1 & 1 & 1 & -1 \\
\hline
\end{tabular}

Tab. 4. Starting matrix in 2018

\begin{tabular}{|c|c|c|c|c|c|c|}
\hline Mining Enterprise & X1 - ROA & $\begin{array}{c}\text { X2 - Inventory } \\
\text { Turnover ratio }\end{array}$ & X3 - Debt ratio & $\begin{array}{c}\text { X } 4 \text { - Cash } \\
\text { ratio }\end{array}$ & $\begin{array}{c}\text { X5 - Productivity } \\
\text { of LTTA }\end{array}$ & $\begin{array}{c}\text { X6 - NWC } \\
\text { turnover ratio }\end{array}$ \\
\hline KERACLAY, a.s. & $8.24 \%$ & 10.13 & $16.86 \%$ & 1.09 & 0.96 & 303.43 \\
\hline LB MINERALS, s.r.o. & $8.01 \%$ & 13.49 & $48.71 \%$ & 0.31 & 0.87 & 1.64 \\
\hline Sedlecký kaolin a. s. & $3.40 \%$ & 6.11 & $40.89 \%$ & 0.26 & 1.08 & 58.01 \\
\hline KERAMOST, a.s. & $2.26 \%$ & 1.65 & $52.84 \%$ & 0.15 & 3.74 & 77.21 \\
\hline Kaolin Hlubany, a.s. & $4.61 \%$ & 13.18 & $22.83 \%$ & 1.03 & 1.65 & 434.80 \\
\hline Granit Lipnice, s.r.o. & $3.10 \%$ & 6.25 & $20.88 \%$ & 1.30 & 4.95 & 134.96 \\
\hline HERLIN spol. s r.o. & $0.12 \%$ & 3.53 & $69.44 \%$ & 0.18 & 1.31 & 54.92 \\
\hline Plzeňská žula a.s. & $2.04 \%$ & 62.33 & $29.03 \%$ & 0.74 & 3.84 & 15.63 \\
\hline Průmysl kamene a.s. & $0.66 \%$ & 3.95 & $1.08 \%$ & 0.45 & 1.16 & 96.46 \\
\hline CEMEX Sand, k.s. & $5.29 \%$ & 23.88 & $79.45 \%$ & 0.10 & 2.66 & - \\
\hline $\begin{array}{c}\text { Ceské štěrkopísky spol. s } \\
\text { r.o. }\end{array}$ & $16.16 \%$ & 186.71 & $44.09 \%$ & 0.49 & 1.05 & 124.72 \\
\hline Českomoravský šterk, a.s. & $12.27 \%$ & 14.06 & $30.53 \%$ & 0.31 & 1.65 & 124.04 \\
\hline $\begin{array}{c}\text { EUROVIA Kamenolomy, } \\
\text { a.s. }\end{array}$ & $19.89 \%$ & 23.01 & $41.05 \%$ & 0.53 & 1.83 & 78.67 \\
\hline $\begin{array}{c}\text { KÁMEN Zbraslav, a.s. } \\
\text { KAMENOLOMY ČR } \\
\text { s.r.o. }\end{array}$ & $12.23 \%$ & 60.84 & $48.94 \%$ & 1.12 & 1.55 & 212.37 \\
\hline
\end{tabular}




\begin{tabular}{|c|c|c|c|c|c|c|}
\hline $\begin{array}{c}\text { HELUZ cihlářský průmysl } \\
\text { v.o.s. }\end{array}$ & $14.06 \%$ & 7.99 & $14.07 \%$ & 2.04 & 0.97 & 208.23 \\
\hline Wienerberger s.r.o. & $33.78 \%$ & 9.24 & $68.02 \%$ & 0.10 & 2.40 & 995.37 \\
\hline Cihelna Hodonín, s.r.o. & $-4.34 \%$ & 0.56 & $322.70 \%$ & 0.01 & 0.03 & - \\
\hline Severočeské doly a.s. & $4.13 \%$ & 21.84 & $24.78 \%$ & 1.50 & 0.43 & 210.32 \\
\hline $\begin{array}{l}\text { Sokolovská uhelná, právní } \\
\text { nástupce, a.s. }\end{array}$ & $2.27 \%$ & 14.46 & $29.10 \%$ & 3.33 & 0.86 & 306.93 \\
\hline Vršanská uhelná a.s. & $2.24 \%$ & 171.42 & $66.57 \%$ & 2.79 & 0.64 & 268.83 \\
\hline Severní energetická a.s. & $-5.39 \%$ & 42.24 & $84.89 \%$ & 2.03 & 0.97 & 236.24 \\
\hline Green Gas DPB, a.s. & $16.27 \%$ & 448.69 & $66.58 \%$ & 1.13 & 2.68 & 285.85 \\
\hline MND a.s. & $-0.25 \%$ & 20.24 & $73.96 \%$ & 0.10 & 10.40 & 13.73 \\
\hline LAMA GAS \& OIL s.r.o. & $2.90 \%$ & 128.24 & $2.37 \%$ & 1.34 & 2.59 & 1059.46 \\
\hline OKD, a.s. & $13.98 \%$ & 0.19 & $79.48 \%$ & 2.48 & 0.08 & - \\
\hline $\begin{array}{c}\text { Českomoravský cement, } \\
\text { a.s. }\end{array}$ & $19.12 \%$ & 14.81 & $53.52 \%$ & 0.08 & 1.46 & 104.42 \\
\hline $\begin{array}{l}\text { Velkolom Čertovy } \\
\text { schody, akciová } \\
\text { společnost }\end{array}$ & $0.88 \%$ & 121.52 & $26.77 \%$ & 1.96 & 0.98 & 582.04 \\
\hline $\begin{array}{c}\text { KOTOUČ } \\
\text { ŠTRAMBERK, spol. s r. } \\
\text { o. }\end{array}$ & $3.53 \%$ & 12.73 & $11.70 \%$ & 0.04 & 0.94 & J02.07 \\
\hline $\begin{array}{c}\text { Cement Hranice, akciová } \\
\text { společnost }\end{array}$ & $32.24 \%$ & 9.63 & $19.79 \%$ & 1.84 & 1.70 & 157.24 \\
\hline Weight & $51.65 \%$ & $4.83 \%$ & $20.65 \%$ & $6.59 \%$ & $12.08 \%$ & $4.20 \%$ \\
\hline Character of indicator & 1 & 1 & -1 & 1 & 1 & -1 \\
\hline
\end{tabular}

In order to be able to evaluate the starting matrices by the chosen method of WSA, it was necessary first to create the ideal variant and basic variant (Tab. 5). In accordance with the methodology, mining companies are evaluated, see Tab. 6.

\begin{tabular}{|c|c|c|c|c|c|c|c|c|}
\hline $\begin{array}{c}\text { benchmark/yea } \\
\text { r }\end{array}$ & 2011 & 2012 & 2013 & 2014 & 2015 & 2016 & 2017 & 2018 \\
\hline \multirow[t]{2}{*}{ X1 - ROA } & $35.45 \%$ & $35.13 \%$ & $28.31 \%$ & $22.34 \%$ & $26.21 \%$ & $26.44 \%$ & $29.98 \%$ & $33.78 \%$ \\
\hline & $-10.25 \%$ & $-29.18 \%$ & $-98.95 \%$ & $-64.46 \%$ & $-97.83 \%$ & $-56.74 \%$ & $-27.30 \%$ & $-5.39 \%$ \\
\hline \multirow{2}{*}{$\begin{array}{l}\text { X2 - Inventory } \\
\text { turnover ratio }\end{array}$} & 955.78 & 619.08 & 1050.21 & 2817.83 & 566.57 & 233.89 & 328.44 & 448.69 \\
\hline & 0.00 & 0.00 & 0.00 & 2.11 & 2.47 & 1.26 & 1.65 & 0.19 \\
\hline \multirow[t]{2}{*}{ X3 - Debt ratio } & $5.47 \%$ & $4.58 \%$ & $5.45 \%$ & $2.32 \%$ & $1.75 \%$ & $3.36 \%$ & $0.99 \%$ & $1.08 \%$ \\
\hline & $145.01 \%$ & $187.51 \%$ & $238.99 \%$ & $267.44 \%$ & $278.08 \%$ & $308.90 \%$ & $407.21 \%$ & $322.70 \%$ \\
\hline \multirow[t]{2}{*}{ X4 - Cash ratio } & 6.94 & 5.50 & 5.27 & 5.82 & 2.78 & 3.41 & 4.43 & 3.33 \\
\hline & 0.01 & 0.00 & 0.01 & 0.01 & 0.01 & 0.01 & 0.01 & 0.01 \\
\hline \multirow{2}{*}{$\begin{array}{c}\text { X5 - } \\
\text { Productivity of } \\
\text { LTTA }\end{array}$} & 4.03 & 4.62 & 5.25 & 9.05 & 7.52 & 8.29 & 15.85 & 10.40 \\
\hline & 0.00 & 0.05 & 0.04 & 0.04 & 0.06 & 0.05 & 0.05 & 0.03 \\
\hline \multirow{2}{*}{$\begin{array}{l}\mathrm{X} 6-\mathrm{NWC} \\
\text { turnover ratio }\end{array}$} & 18.98 & 6.66 & 4.51 & 4.25 & 10.13 & 5.85 & 0.14 & 1.64 \\
\hline & $\begin{array}{c}128848.7 \\
2\end{array}$ & 1451588.41 & 2371889.23 & 2750420.71 & 2256718.24 & 3059267.52 & 3907367.20 & 7390897.30 \\
\hline
\end{tabular}

The next steps of the evaluation are standardisation of benchmark values, using equations (7) and (8) and determining the value of the overall benefit by relation (9). Tab. 6 shows the values of the overall benefit achieved by the evaluated enterprises in the monitored period.

\begin{tabular}{|c|c|c|c|c|c|c|c|c|c|c|}
\hline \multicolumn{10}{|c|}{ Tab. 6. Overall benefit in the period 2011-2018 } \\
\hline Mining Enterprise & 2011 & 2012 & 2013 & 2014 & 2015 & 2016 & 2017 & 2018 & AVG & $\begin{array}{c}\text { Standard } \\
\text { deviation }\end{array}$ \\
\hline KERACLAY, a.s. & 0.36 & 0.50 & 0.71 & 0.71 & 0.72 & 0.67 & 0.58 & 0.45 & 0.59 & 0.138441251 \\
\hline LB MINERALS, s.r.o. & 0.40 & 0.50 & 0.66 & 0.65 & 0.69 & 0.65 & 0.57 & 0.41 & 0.57 & 0.116401922 \\
\hline Sedlecký kaolin a. s. & 0.34 & 0.47 & 0.60 & 0.63 & 0.66 & 0.60 & 0.50 & 0.36 & 0.52 & 0.124809205 \\
\hline KERAMOST, a.s. & 0.43 & 0.49 & 0.69 & 0.67 & 0.69 & 0.64 & 0.55 & 0.36 & 0.57 & 0.127437184 \\
\hline Kaolin Hlubany, a.s. & 0.47 & 0.58 & 0.71 & 0.72 & 0.73 & 0.69 & 0.61 & 0.41 & 0.62 & 0.122393815 \\
\hline
\end{tabular}




\begin{tabular}{|c|c|c|c|c|c|c|c|c|c|c|}
\hline Granit Lipnice, s.r.o. & 0.48 & 0.63 & 0.72 & 0.71 & 0.75 & 0.69 & 0.55 & 0.43 & 0.62 & 0.119950596 \\
\hline HERLIN spol. s r.o. & 0.39 & 0.55 & 0.73 & 0.71 & 0.69 & 0.59 & 0.47 & 0.30 & 0.55 & 0.157419555 \\
\hline Plzeňská žula a.s. & 0.37 & 0.49 & 0.72 & 0.69 & 0.67 & 0.65 & 0.51 & 0.39 & 0.56 & 0.138916175 \\
\hline Průmysl kamene a.s. & 0.45 & 0.51 & 0.68 & 0.65 & 0.67 & 0.61 & 0.53 & 0.35 & 0.56 & 0.118321853 \\
\hline CEMEX Sand, k.s. & 0.35 & 0.47 & 0.62 & 0.60 & 0.63 & 0.64 & 0.52 & 0.37 & 0.53 & 0.115946669 \\
\hline $\begin{array}{c}\text { České štěrkopísky spol. s } \\
\text { r.o. }\end{array}$ & 0.41 & 0.56 & 0.66 & 0.70 & 0.73 & 0.63 & 0.55 & 0.55 & 0.60 & 0.103564538 \\
\hline Českomoravský štěrk, a.s. & 0.43 & 0.52 & 0.67 & 0.67 & 0.71 & 0.67 & 0.59 & 0.49 & 0.59 & 0.103509039 \\
\hline $\begin{array}{c}\text { EUROVIA Kamenolomy, } \\
\text { a.s. }\end{array}$ & 0.44 & 0.60 & 0.69 & 0.72 & 0.79 & 0.74 & 0.65 & 0.59 & 0.65 & 0.108619205 \\
\hline KÁMEN Zbraslav, a.s. & 0.45 & 0.53 & 0.69 & 0.70 & 0.75 & 0.73 & 0.62 & 0.50 & 0.62 & 0.112430335 \\
\hline KAMENOLOMY ČR s.r.o. & 0.51 & 0.61 & 0.71 & 0.70 & 0.73 & 0.71 & 0.61 & 0.50 & 0.64 & 0.091506216 \\
\hline $\begin{array}{l}\text { HELUZ cihlářský průmysl } \\
\text { v.o.s. }\end{array}$ & 0.43 & 0.53 & 0.67 & 0.69 & 0.69 & 0.67 & 0.63 & 0.55 & 0.61 & 0.096121687 \\
\hline Wienerberger s.r.o. & 0.43 & 0.42 & 0.58 & 0.62 & 0.64 & 0.64 & 0.65 & 0.75 & 0.59 & 0.113829036 \\
\hline Cihelna Hodonín, s.r.o. & 0.01 & 0.00 & 0.28 & 0.31 & 0.39 & 0.29 & 0.18 & 0.01 & 0.18 & 0.157280895 \\
\hline Severočeské doly a.s. & 0.56 & 0.58 & 0.71 & 0.68 & 0.73 & 0.71 & 0.54 & 0.40 & 0.61 & 0.116241313 \\
\hline $\begin{array}{c}\text { Sokolovská uhelná, právní } \\
\text { nástupce, a.s. }\end{array}$ & 0.49 & 0.57 & 0.74 & 0.70 & 0.72 & 0.70 & 0.57 & 0.41 & 0.61 & 0.122208953 \\
\hline Vršanská uhelná a.s. & 0.46 & 0.54 & 0.70 & 0.64 & 0.68 & 0.61 & 0.55 & 0.39 & 0.57 & 0.108825231 \\
\hline Severní energetická a.s. & 0.45 & 0.62 & 0.72 & 0.69 & 0.76 & 0.65 & 0.55 & 0.25 & 0.59 & 0.166720413 \\
\hline Green Gas DPB, a.s. & 0.54 & 0.65 & 0.72 & 0.72 & 0.73 & 0.70 & 0.68 & 0.59 & 0.67 & 0.068844828 \\
\hline MND a.s. & 0.43 & 0.63 & 0.79 & 0.74 & 0.76 & 0.70 & 0.50 & 0.39 & 0.62 & 0.15734514 \\
\hline LAMA GAS \& OIL s.r.o. & 0.80 & 0.87 & 0.83 & 0.81 & 0.72 & 0.63 & 0.58 & 0.43 & 0.71 & 0.152942487 \\
\hline OKD, a.s. & 0.54 & 0.50 & 0.21 & 0.19 & 0.25 & 0.22 & 0.43 & 0.50 & 0.36 & 0.150041629 \\
\hline Českomoravský cement, a.s. & 0.51 & 0.58 & 0.70 & 0.66 & 0.67 & 0.68 & 0.63 & 0.56 & 0.62 & 0.067411466 \\
\hline $\begin{array}{l}\text { Velkolom Čertovy schody, } \\
\text { akciová společnost }\end{array}$ & 0.39 & 0.53 & 0.71 & 0.80 & 0.72 & 0.66 & 0.55 & 0.38 & 0.59 & 0.155466217 \\
\hline $\begin{array}{l}\text { KOTOUČ ŠTRAMBERK, } \\
\text { spol. s r. o. }\end{array}$ & 0.48 & 0.52 & 0.70 & 0.66 & 0.72 & 0.63 & 0.49 & 0.37 & 0.57 & 0.1237027 \\
\hline $\begin{array}{c}\text { Cement Hranice, akciová } \\
\text { společnost }\end{array}$ & 0.72 & 0.68 & 0.76 & 0.80 & 0.84 & 0.83 & 0.79 & 0.79 & 0.78 & 0.053056704 \\
\hline
\end{tabular}

Although the values of overall benefits already indicate the position of mining companies, they are only a starting point for determining the ranking of mining companies in the reference period. This ranking clearly and comprehensively shows not only the achieved results in the individual years of the period 2011-2018 but also the company's development in this period, see Tab. 7. Ranking standard deviation indicates whether the development of the mining company is stable or significant changes in the company's position.

Tab. 7. Order of mining enterprises in the reference period

\begin{tabular}{|c|c|c|c|c|c|c|c|c|c|c|c|c|}
\hline Mining Enterprise & 2011 & 2012 & 2013 & 2014 & 2015 & 2016 & 2017 & 2018 & SD & $\mathrm{VN}$ & FR & RSD \\
\hline KERACLAY, a.s. & 27 & 22 & 10 & 10 & 16 & 12 & 11 & 12 & 6.30 & 120 & 14 & 19 \\
\hline LB MINERALS, s.r.o. & 23 & 23 & 25 & 24 & 20 & 16 & 14 & 15 & 4.41 & 160 & 23 & 13 \\
\hline Sedlecký kaolin a. s. & 29 & 28 & 27 & 26 & 26 & 27 & 25 & 26 & 1.28 & 214 & 29 & 3 \\
\hline Kaolin Hlubany, a.s. & 11 & 10 & 11 & 5 & 10 & 9 & 9 & 17 & 3.33 & 82 & 7 & 8 \\
\hline Granit Lipnice, s.r.o. & 9 & 5 & 6 & 8 & 5 & 10 & 15 & 13 & 3.68 & 71 & 6 & 9 \\
\hline HERLIN spol. s r.o. & 25 & 14 & 5 & 9 & 21 & 28 & 28 & 28 & 9.25 & 158 & 21 & 28 \\
\hline Plzeňská žula a.s. & 26 & 25 & 8 & 17 & 24 & 17 & 24 & 20 & 6.03 & 161 & 24 & 17 \\
\hline Průmysl kamene a.s. & 15 & 21 & 21 & 23 & 25 & 26 & 22 & 27 & 3.78 & 180 & 26 & 10 \\
\hline CEMEX Sand, k.s. & 28 & 27 & 26 & 28 & 28 & 21 & 23 & 23 & 2.78 & 204 & 28 & 5 \\
\hline $\begin{array}{c}\text { České štěrkopísky spol. s } \\
\text { r.o. }\end{array}$ & 22 & 13 & 24 & 14 & 7 & 22 & 18 & 7 & 6.71 & 127 & 17 & 22 \\
\hline
\end{tabular}




\begin{tabular}{|c|c|c|c|c|c|c|c|c|c|c|c|c|}
\hline Českomoravský štěrk, a.s. & 18 & 19 & 22 & 20 & 17 & 13 & 10 & 11 & 4.40 & 130 & 18 & 12 \\
\hline $\begin{array}{c}\text { EUROVIA Kamenolomy, } \\
\text { a.s. }\end{array}$ & 16 & 8 & 18 & 7 & 2 & 2 & 3 & 4 & 6.28 & 60 & 3 & 18 \\
\hline KÁMEN Zbraslav, a.s. & 13 & 16 & 20 & 11 & 6 & 3 & 7 & 10 & 5.55 & 86 & 9 & 15 \\
\hline $\begin{array}{c}\text { KAMENOLOMY ČR } \\
\text { s.r.o. } \\
\end{array}$ & 7 & 7 & 12 & 13 & 9 & 5 & 8 & 9 & 2.66 & 70 & 5 & 4 \\
\hline $\begin{array}{c}\text { HELUZ cihlářský } \\
\text { průmysl v.o.s. }\end{array}$ & 21 & 18 & 23 & 16 & 19 & 14 & 5 & 6 & 6.63 & 122 & 15 & 20 \\
\hline Wienerberger s.r.o. & 20 & 29 & 28 & 27 & 27 & 19 & 4 & 2 & 10.84 & 156 & 20 & 30 \\
\hline Cihelna Hodonín, s.r.o. & 30 & 30 & 29 & 29 & 29 & 29 & 30 & 30 & 0.53 & 236 & 30 & 1 \\
\hline Severočeské doly a.s. & 3 & 9 & 14 & 18 & 8 & 4 & 21 & 18 & 6.83 & 95 & 11 & 23 \\
\hline $\begin{array}{c}\text { Sokolovská uhelná, právní } \\
\text { nástupce, a.s. }\end{array}$ & 8 & 12 & 4 & 12 & 12 & 7 & 13 & 16 & 3.85 & 84 & 8 & 11 \\
\hline Vršanská uhelná a.s. & 12 & 15 & 15 & 25 & 22 & 25 & 20 & 21 & 4.87 & 155 & 19 & 14 \\
\hline Severní energetická a.s. & 14 & 6 & 9 & 15 & 3 & 18 & 17 & 29 & 8.11 & 111 & 13 & 25 \\
\hline Green Gas DPB, a.s. & 4 & 3 & 7 & 6 & 11 & 6 & 2 & 3 & 2.92 & 42 & 2 & 6 \\
\hline MND a.s. & 19 & 4 & 2 & 4 & 4 & 8 & 26 & 19 & 9.18 & 86 & 9 & 27 \\
\hline LAMA GAS \& OIL s.r.o. & 1 & 1 & 1 & 1 & 13 & 23 & 12 & 14 & 8.43 & 66 & 4 & 26 \\
\hline $\mathrm{OKD}$, a.s. & 5 & 24 & 30 & 30 & 30 & 30 & 29 & 8 & 10.57 & 186 & 27 & 29 \\
\hline $\begin{array}{c}\text { Českomoravský cement, } \\
\text { a.s. }\end{array}$ & 6 & 11 & 16 & 22 & 23 & 11 & 6 & 5 & 7.15 & 100 & 12 & 24 \\
\hline $\begin{array}{c}\text { Velkolom Čertovy } \\
\text { schody, akciová } \\
\text { společnost } \\
\end{array}$ & 24 & 17 & 13 & 2 & 14 & 15 & 16 & 22 & 6.63 & 123 & 16 & 21 \\
\hline $\begin{array}{c}\text { KOTOUČ } \\
\text { ŠTRAMBERK, spol. s r. } \\
\text { o. } \\
\end{array}$ & 10 & 20 & 17 & 21 & 15 & 24 & 27 & 24 & 5.55 & 158 & 21 & 15 \\
\hline $\begin{array}{c}\text { Cement Hranice, akciová } \\
\text { společnost }\end{array}$ & 2 & 2 & 3 & 3 & 1 & 1 & 1 & 1 & 0.89 & 14 & 1 & 2 \\
\hline
\end{tabular}

SD - Standard deviation, VN - Value number, FR - Final ranking, RSD - Ranking standard deviation

If we narrow our results, the best mining companies are: (1) Cement Hranice, akciová společnost, (2) Green Gas DPB, a.s., (3) EUROVIA Kamenolomy, a.s. At the opposite end of the list are: (28) CEMEX Sand, k.s., (29) Sedlecký Kaolín, a. s., (30) Cihelna Hodonín, s.r.o.

\section{Discussion}

Our benchmarking project included a total of 30 mining companies out of a total of 232 enterprises, which is $12.93 \%$. However, taking into account that the mining companies that achieved the highest production in the reference year 2017 were included in the benchmarking project, see Tab. 8, then the set of enterprises can be considered relevant.

Tab. 8. Share of extraction of selected enterprises in total extraction by raw material in 2017

\begin{tabular}{|c|c|c|c|c|}
\hline Raw material & Units & Total mining output & $\begin{array}{l}\text { Mining output of selected } \\
\text { enterprises }\end{array}$ & $\begin{array}{c}\text { Mining output of selected } \\
\text { enterprises in total production in } \\
\%\end{array}$ \\
\hline Hard Coal & $10^{3} \mathrm{t}$ & 4870 & 4870 & $100 \%$ \\
\hline Brown Coal & $10^{3} \mathrm{t}$ & 39416 & 39416 & $100 \%$ \\
\hline Crude Oil & $10^{3} \mathrm{t}$ & 106.5 & 106.5 & $100 \%$ \\
\hline Natural Gas & $10^{6} \mathrm{~m}^{3}$ & 220.5 & 219.5 & $99.55 \%$ \\
\hline Gravel Sand and Sands & $\mathrm{m}^{3}$ & 10087790 & 5500248 & $54.52 \%$ \\
\hline Construction Stone & $\mathrm{m}^{3}$ & 14504312 & 8183946 & $56.42 \%$ \\
\hline Brick Clays & $\mathrm{m}^{3}$ & 704202 & 695882 & $98.82 \%$ \\
\hline Dimension Stone & $\mathrm{m}^{3}$ & 134144 & 86178 & $64.24 \%$ \\
\hline Limestone & $\mathrm{t}$ & 10345150 & 6698796 & $64.75 \%$ \\
\hline Kaolin & $\mathrm{t}$ & & 4024801 & $\operatorname{cca} 90 \%$ \\
\hline Clays and Bentonite & $\mathrm{t}$ & 758883 & 690847 & $91.03 \%$ \\
\hline
\end{tabular}

Although our benchmarking project was based on a comparison of selected mining companies, the chosen method of evaluation brings our project closer to the essence of benchmarking. The method of WSA compares enterprises with an ideal variant and basic variant that shows the best values for the selected benchmarks. The 
achieved overall and partial results thus enable us to identify opportunities for measures to improve the current situation.

Ranking standard deviation offers another dimension to evaluate the comparison of mining companies. The first place went to Cihelna Hodonín, s.r.o., which was placed in $30^{\text {th }}$ place in the final ranking. The second and third came Cement Hranice, a.s. and Sedlecký Kaolin, a.s., respectively. At the other end ranked Wienerberger, s. r. o. (30), OKD, a. s. (29), HERLIN spol. s r.o. (28).

As in other areas, the relative aspect must be mentioned when assessing the stability of the company's development. If the company has consistently achieved excellent results such as Cement Hranice, akciová společnost and Green Gas DPB, a.s., which ranked in the final ranking in the TOP 5, then this state can only be evaluated positively and appreciated by the management of these companies. However, Cihelna Hodonín, s.r.o. deserves the opposite assessment, as it has been struggling for a long time with poor results and the company's management has apparently failed to find suitable measures to get the company from the economically unfavourable situation.

Let us look further at the results achieved in terms of focusing mining companies on groups of mined raw materials. Looking at Tab. 7, we find that in the final ranking in TOP 5 is Cement Hranice, joint-stock company (1) - limestone, Green Gas DPB, a.s. (2) - energy raw materials (natural gas), EUROVIA Kamenolomy, a.s. (3) construction raw materials (building stone), LAMA GAS \& OIL s.r.o. (4) - energy raw materials (oil, natural gas), KAMENOLOMY ČR s.r.o. (5) - gravel, construction raw materials.

At the opposite end of the list are: Cihelna Hodonín, s.r.o. (30) - building materials (brick-making material), Sedlecký kaolin, a.s. (29) - kaolin, CEMEX Sand, k.s. (28) - building materials (gravel and sand), OKD, a.s. (27) - energetic raw material (coal), Stone Industry Inc. (26) - building materials (decorative stone).

The analysis shows that companies from both groups (successful, unsuccessful) have the benefit of different raw material groups, and it cannot be said that the economic success/failure of the mining company is a reflection of minerals. While it is true that among the unsuccessful companies prevail companies exploiting building materials, EUROVIA kamenolomy, a.s. mining building stone took third place in the final rank. Although two mining companies exploiting energy raw materials ranked in the TOP 5, the group of unsuccessful companies also included a company focusing exclusively on energy raw materials (OKD, a.s.).

For the sake of completeness, we would like to state that OKD, a.s. has been struggling for a long time with financial problems that resulted in insolvency in May 2016.

The fact that companies focusing on the extraction of construction raw materials achieved rather average to below average results may be due to the fact that at the beginning of the monitored period 2011-2018 were the economic recession. The economic recession was the cause of to decline in construction output and thus in demand for construction raw materials. All the more valuable is the success of EUROVIA kamenolomy, a.s.

The following Tab. 9 shows the benchmark values for Cement Hranice, akciová společnost between 2011 and 2018. The table can thus serve as an inspiration for the target values for other miners operating in the Czech Republic.

Tab. 9. Benchmark values of Cement Hranice, joint stock company in the period $2011-2018$

\begin{tabular}{|c|c|c|c|c|c|c|c|c|}
\hline Financial Ratios & 2011 & 2012 & 2013 & 2014 & 2015 & 2016 & 2017 & 2018 \\
\hline X1 - ROA & $28.58 \%$ & $22.40 \%$ & $19.25 \%$ & $22.34 \%$ & $26.21 \%$ & $26.44 \%$ & $29.98 \%$ & $32.24 \%$ \\
\hline $\begin{array}{c}\mathrm{X} 2 \text { - Inventory } \\
\text { turnover ratio }\end{array}$ & 11.00 & 10.43 & 7.56 & 9.50 & 9.72 & 12.87 & 9.97 & 9.63 \\
\hline $\mathrm{X} 3$ - Debt ratio & $20.13 \%$ & $22.07 \%$ & $15.99 \%$ & $14.88 \%$ & $16.00 \%$ & $17.14 \%$ & $17.67 \%$ & $19.79 \%$ \\
\hline $\mathrm{X} 4$ - Cash ratio & 0.58 & 0.13 & 0.60 & 2.27 & 2.59 & 2.66 & 1.57 & 1.84 \\
\hline $\begin{array}{c}\text { X5 - Productivity } \\
\text { of LTTA }\end{array}$ & 1.68 & 1.51 & 1.28 & 1.42 & 1.47 & 1.44 & 1.55 & 1.70 \\
\hline $\begin{array}{c}\mathrm{X} 6-\mathrm{NWC} \\
\text { turnover ratio }\end{array}$ & 175.04 & 180.09 & 281.94 & 233.50 & 196.15 & 191.49 & 151.02 & 157.24 \\
\hline
\end{tabular}

Comparing Tab. 9 with Tab. 5, we find that they are not identical. For the management of Cement Hranice, akciová společnost, it means that even for the best business, there are opportunities for improvement. For other companies, however, Cement Hranice, a joint-stock company, may be a model, despite the fact that in the whole reporting period, a benchmark of compliance with the benchmark of the ideal variant was achieved only in four cases. So, the secret of success lies in the stability of excellent results, even though it may not be the best in all the monitored criteria.

We have formulated four hypotheses at the beginning of our work, which we will now focus on in more detail.

The first hypothesis assumes that with the increasing volume of mining, the company's economic success will grow. To confirm or refute the hypothesis, the authors used correlation analyses, correlating the ranking of the mining company with regard to the economic success and the ranking of the mining company according to the 
size of mining in the monitored period 2011-2018. Since the correlation coefficient was 0.3651 , it can be stated that the hypothesis was disproved.

The second hypothesis assumes that economically more successful are those mining companies that specialise in the extraction of one mineral. In the group of 30 mining enterprises, 12 enterprises (40\%) are producing more than one mineral, see Tab. 10. Three subgroups can be created in this group: stone and gravel mining companies and kaolin, clay and mining companies focus on bentonite. The third subgroup consists of oil and gas exploiting miners. These are related raw material subgroups. LB Minerals, s.r.o., which mines raw materials, gravel, gravel, kaolin, clays and bentonite, stands out from all groups.

\begin{tabular}{|c|c|c|}
\hline \multicolumn{2}{|c|}{ Tab. 10. Overview of mining companies with more mined raw materials } \\
\hline Mining Enterprise & Number of mined raw materials & $\begin{array}{c}\text { Ranking of the company in the } \\
\text { final rank }\end{array}$ \\
\hline LB MINERALS, s.r.o. & 4 & 23 \\
\hline Sedlecký kaolin a. s. & 2 & 29 \\
\hline KERAMOST, a. s. & 2 & 25 \\
\hline Kaolin Hlubany, a. s. & 2 & 7 \\
\hline CEMEX Sand, k. s. & 3 & 18 \\
\hline Českomoravský štěrk, a. s. & 2 & 3 \\
\hline EUROVIA Kamenolomy, a.s. & 2 & $9-10$ \\
\hline KÁMEN Zbraslav, a. s. & 2 & 5 \\
\hline KAMENOLOMY ČR s.r.o. & 2 & 8 \\
\hline Sokolovská uhlelná, právní nástupce a. s. & 2 & $9-10$ \\
\hline MND, a. s. & 2 & 4 \\
\hline LAMA GAS\&OIL, s. r. o. & 2 & \\
\hline
\end{tabular}

For better clarity, in Tab. 10, mining companies mining more than one raw material located in the TOP 10 were identified in green; the remaining companies were then blue. Tab. 10 shows that green companies prevail compared to blue companies at 7:5. However, this result does not give an unequivocal answer. If we look at the findings of Tab. 10 through a slightly different lens, then it can be said that in the TOP 10, 70\% of companies extract more than one mineral. In the remaining group of 20 companies, then $75 \%$ of companies extract only one raw material. It can therefore be considered from these findings that companies extracting more than one raw material are more successful than those focusing on one raw material. Specialisation is thus not a successful strategy, and hypothesis 2 has not been confirmed.

In the case of the third hypothesis, correlation analysis was used again for its acceptance or rejection, similarly to the first hypothesis. The correlation index was 0.3780 , leading to the failure to accept the mining company's low indebtedness as a result of the mining's economic success.

Similarly to other research (Vaněk, 2011; Knapková, 2018), we paid attention to the effect of the companies' legal form on the economic results. The fourth hypothesis focused on the relationship between the company's economic success and its legal form, namely Limited Liability Company and Joint Stock Company. It is clear from Tab. 11 that, on average, joint-stock companies are more successful than limited liability companies and therefore, the hypothesis can be considered as confirmed.

Tab. 11. Overview of mining companies and their performance by legal form

\begin{tabular}{|c|c|c|c|c|}
\hline & $\begin{array}{c}\text { Abbreviation used in } \\
\text { Czech }\end{array}$ & $\begin{array}{c}\text { Number of } \\
\text { Enterprises }\end{array}$ & Value Number & AWG \\
\hline Legal Form of Mining Enterprise & v.o.s. & 1 & 122 & 22.0 \\
\hline Public Company & k.s. & 1 & 1204 & 204.0 \\
\hline Limited Partnership & s.r.o. & 1365 & 2029 & 136.5 \\
\hline Jimited Liability Company & a.s. & 18 & 2.7 \\
\hline
\end{tabular}

\section{Conclusion}

The authors do not know that a similar benchmarking project (study) has been implemented in the Czech Republic to compare mining companies across raw material groups. Since ours is not only a comparison but also offers more detailed analyses, we believe that it can serve not only for educational or scientific research purposes, but the study can provide valuable information for mining company managers.

For managers of specific mining companies, the study can become the starting point for the subsequent search for measures to maintain or rather improve the current situation, which could bring their business results closer to the prime mining company among the mining companies

Undoubtedly, these are the TOP 5 companies, which are: Cement Hranice, akciová společnost (1) - limestone, Green Gas DPB, a.s. (2) - energy raw materials (natural gas), EUROVIA Kamenolomy, a.s. (3) - construction raw 
materials (building stone), LAMA GAS \& OIL s.r.o. (4) - energy raw materials (oil, natural gas), KAMENOLOMY ČR s.r.o. (5) - gravel, construction raw materials.

The purpose of our article was also to search for knowledge that would confirm or disprove the hypotheses formulated in the introduction. The analyses have led to the following conclusions: (H1) - not accepted, (H2) - not accepted, (H3) - not accepted, (H4) - accepted. We are convinced that this result put more precisely the initial view of the studied issue, especially the factors influencing the economic success of mining companies. Although our study examined the subject relatively broadly, the knowledge gained offers further possibilities for scientific research. The created database of mining companies can be further expanded, on the one hand, to companies exploiting less important raw materials and, on the other hand, with companies with smaller volumes of extraction. Since hypothesis H1, which focused on the relationship between mining volume and economic success, has not been confirmed, it is possible that a group of mining companies exploiting smaller volumes of minerals may find a new prime company among mining companies. The new prime company would become a new pattern to which other mining companies should be their economic performance to approach.

\section{References}

Anderson, D. R., Sweeney, D. J., Williams, T. A. (1994). An introduction to management science: Quantitative approaches to decision making. West Publ., Minneapolis.

Arnold, J., Minner, S., Eidam, B. (2009). Raw material procurement with fluctuating prices. International Journal of Production Economics. doi: 10.1016/j.ijpe.2007.02.038.

Brealey, R. et al. (2018). Fundamentals of corporate finance. ninth ed., international ed., McGraw-Hill/Irwin, New York.

Brigham E., Ehrhardt M. (2014). Financial Management: Theory and Practice. thirteenth ed., South-Western: Cengage Learning, Mason.

Cross R., Iqbal A. (1995). The Rank Xerox Experience: Benchmarking Ten Years On. In: Rolstadås A. (eds) Benchmarking - Theory and Practice. IFIP Advances in Information and Communication Technology. Springer, Boston, MA. https://doi.org/10.1007/978-0-387-34847-6_1.

Čech, J., Šofranko, M. (2018). Economic projection and evaluation of mining venture. E a M Ekon. a Manag, 21(2), pp 38-52, doi: 10.15240/tul/001/2018-2-003.

Černý, I. et al (2019). An analysis of selected benchmarks and evaluation methods to test the replacebility of mathematical-statistical methods in benchmarking by solvency and bankruptcy models: A case study in assessing gravel-sand mining companies in the Czech Republic., Inżynieria Mineralna. 43(1), 315-326.

https://data.mendeley.com/drafts/7h6wkxs5vv.

Fordham, F. (2004). Mining company performance improvement programs and results - Summary of benchmarking study. In: Annual Meeting of the Society-for-Mining-Metallurgy-and-Exploration. Denver: The Society-for-Mining-Metallurgy-and-Exploration, pp.19-24.

Goncharuk A.G., Lazareva N.O., Alsharf I.A.M. (2015). Benchmarking as a performance management method. POLISH JOURNAL OF MANAGEMENT STUDIES. 11 (2). (https://www.researchgate.net/publication/282926460_Benchmarking_as_a_performance_management_ method)

Hall, A. J., Harper, P. J. (2005). Benchmarking - A practical technique for measuring and improving operational performance. In: 9TH AUSIMM UNDERGROUND OPERATORS CONFERENCE. Carlton, Vic.: Australasian Institute of Mining and Metallurgy, pp 93-102.

Hornická ročenka (Mining Annual) 2011. Ostrava: Montanex (2012). ISBN 978-80-7225-364-7.

Hornická ročenka (Mining Annual) 2012. Ostrava: Montanex (2013). ISBN 978-80-7225-383-8.

Hornická ročenka (Mining Annual) 2013. Ostrava: Montanex (2014). ISBN 978-80-7225-395-1.

Hornická ročenka (Mining Annual) 2014. Ostrava: Montanex (2015). ISBN 978-80-7225-411-8.

Hornická ročenka (Mining Annual) 2015. Ostrava: Montanex (2016). ISBN 978-80-7225-422-4.

Hornická ročenka (Mining Annual) 2016. Ostrava: Montanex (2017). ISBN 978-80-7225-442-2.

Hornická ročenka (Mining Annual) 2017. Ostrava: Montanex (2018). 278 p. ISBN 978-80-7225-454-5.

Hornická ročenka (Mining Annual) 2018. Ostrava: Montanex (2019). ISBN 978-80-7225-463-7.

Ifeoluwa, A. and Yinshang T. (2010). The Adoption of Benchmarking Principles for Project Management Performance Improvement. International Journal of Managing Public Sector Information and $\begin{array}{lllll}\text { Communication } & \text { Technologies. } & \text { Vol. } & 1, & \text { No. }\end{array}$ (https://www.researchgate.net/publication/228900792_The_Adoption_of_Benchmarking_Principles_for_ Project_Management_Performance_Improvement)

Kotler, P., Keller, K. (2006). Marketing management, twelfth ed. Pearson Education Inc, New Jersey.

Karlöf, B. et al. (1993). Benchmarking, Wiley, Chichester. 
Kazanin, O.I., Rudakov, M.L. (2016). Benchmarking Initiatives in the Field of Occupational Safety and Health in the Context of Development of the Coal Industry of Russia. RESEARCH JOURNAL OF PHARMACEUTICAL BIOLOGICAL AND CHEMICAL SCIENCES, 7(2), pp 2092-2099.

Knápková, M., Krešáková, V. (2018). LEGAL FORMS OF BUSINESS COMPANIES IN SLOVAKIA AND GERMANY - COMPARATIVE ANALYSIS. SOCIÁLNO-EKONOMICKÁ REVUE 9(1) pp32-41.

Krzemien, A. et al. (2016). Beyond the pan-european standard for reporting of exploration results, mineral resources and reserves. Resources Policy, 49. doi: 10.1016/j.resourpol.2016.04.008.

Laciak, M., Šofranko, M. (2013). Designing of the technological line in the SCADA system PROMOTIC. In 14th International Carpathian Control Conference (ICCC). Rytro: IEEE pp202-206.

Lambert, D., Cooper, M. (2000). Issues in supply chain management. Industrial Marketing Management. doi: 10.1016/S0019-8501(99)00113-3.

Ming, J., Hu, N. (2012). The Enterprise Performance Management System for Mining Enterprises. In: International Conference on Materials Science and Information Technology (MSIT 2011). Singapore: Singapore Inst Elect, pp 3276-3283.

Saaty, L. T. (2001). Models, Methods, Concepts \& Applications of the Analytic Hierarchy Process, Springer, USA.

Saaty, L. T. (2008). Decision making with the analytic hierarchy process. Int. J. Services Scientes. 1 (1), 89-98.

Pan, XP., Sha, JH., Zhang, HL., Ke, WL. (2014). Relationship between Corporate Social Responsibility and Financial Performance in the Mineral industry: Evidence from Chinese Mineral Firms. SUSTAINABILITY, 6(7), pp 4077-4101, doi: 10.3390/su6074077.

Production (current price) (2020). Czech Statistical Office. http://apl.czso.cz/pll/rocenka/rocenka.presmsocas (accessed 2 April 2020).

Tsolas, I. (2008). Derivation of mineral processing environmental sustainability indicators using a DEA weightrestricted algorithm. MINERALS \& METALLURGICAL PROCESSING. 25 (4), pp199-205. doi:10.1007/BF03403408

Van Thuyet, N. et al. (2007). Risk management in oil and gas construction projects in Vietnam. International Journal of Energy Sector Management. doi: 10.1108/17506220710761582.

Vaněk, M. et al. (2011). Analysis of Mining Companies Operating in the Czech Republic in the Sector of Nonmetallic and Construction Minerals. Gospodarka Surowcami Mineralnymi, 27(4), pp 17-32.

Vaněk, M. et al. (2013). Benchmarking for major producers of limestone in the Czech Republic. Gospodarka Surowcami Mineralnymi / Mineral Resources Management. 29(1). doi: 10.2478/gospo-2013-0003.

Vaněk, M. et al. (2017). Benchmarking of mining companies extracting hard coal in the Upper Silesian Coal Basin. Resources Policy, 53. doi: 10.1016/j.resourpol.2017.07.010.

Veřejný rejstř́k a sbírka listin (Public Register and the Collection of Documents). Ministerstvo spravedlnosti České republiky [online] (2019). [cited 2019-11-11]. Available from: https://or.justice.cz/ias/ui/rejstrik.

Zairi, M. (2017). Benchmarking for Best Practice, Benchmarking for Best Practice. doi: 10.4324/9780080499994. 
Appendix A

\begin{tabular}{|c|c|c|c|c|c|c|c|c|c|c|c|}
\hline Mining Enterprise/Minerals & Hard Coal & Brown Coal & $\begin{array}{l}\text { Crude } \\
\text { Oil }\end{array}$ & $\begin{array}{c}\text { Natural } \\
\text { Gas }\end{array}$ & Brick Clays & $\begin{array}{l}\text { Construction } \\
\text { Stone }\end{array}$ & $\begin{array}{c}\text { Gravel Sand } \\
\text { and Sands }\end{array}$ & $\begin{array}{l}\text { Dimension } \\
\text { Stone }\end{array}$ & Limestone & Kaolin & $\begin{array}{l}\text { Clays and } \\
\text { Bentonite }\end{array}$ \\
\hline Units & $10^{3} \mathrm{t}$ & $10^{3} \mathrm{t}$ & $10^{3} \mathrm{t}$ & $10^{6} \mathrm{~m}^{3}$ & $\mathrm{~m}^{3}$ & $\mathrm{~m}^{3}$ & $\mathrm{~m}^{3}$ & $\mathrm{~m}^{3}$ & $\mathrm{t}$ & $\mathrm{t}$ & $\mathrm{t}$ \\
\hline KERACLAY, a.s. & 0,0 & 0,0 & 0,0 & 0,0 & 0,0 & 0,0 & 0,0 & 0,0 & 0,0 & 0,0 & 617137,0 \\
\hline LB MINERALS, s.r.o. & 0,0 & 0,0 & 0,0 & 0,0 & 18800,0 & 0,0 & 3273000,0 & 0,0 & 0,0 & 24339000,0 & 2270000,0 \\
\hline Sedlecký kaolin a. s. & 0,0 & 0,0 & 0,0 & 0,0 & 0,0 & 0,0 & 0,0 & 0,0 & 0,0 & 1942603,0 & 709420,0 \\
\hline KERAMOST, a.s. & 0,0 & 0,0 & 0,0 & 0,0 & 0,0 & 0,0 & 0,0 & 0,0 & 0,0 & 766603,0 & 3313903,0 \\
\hline Kaolin Hlubany, a.s. & 0,0 & 0,0 & 0,0 & 0,0 & 0,0 & 0,0 & 0,0 & 0,0 & 0,0 & 1125397,0 & 2361,0 \\
\hline Granit Lipnice, s.r.o. & 0,0 & 0,0 & 0,0 & 0,0 & 0,0 & 0,0 & 0,0 & 110426,0 & 0,0 & 0,0 & 0,0 \\
\hline HERLIN spol. s r.o. & 0,0 & 0,0 & 0,0 & 0,0 & 0,0 & 0,0 & 0,0 & 189785,0 & 0,0 & 0,0 & 0,0 \\
\hline Plzeňská žula a.s. & 0,0 & 0,0 & 0,0 & 0,0 & 0,0 & 0,0 & 0,0 & 70552,0 & 0,0 & 0,0 & 0,0 \\
\hline Průmysl kamene a.s. & 0,0 & 0,0 & 0,0 & 0,0 & 0,0 & 0,0 & 0,0 & 112053,0 & 0,0 & 0,0 & 0,0 \\
\hline CEMEX Sand, k.s. & 0,0 & 0,0 & 0,0 & 0,0 & 0,0 & 3790857,0 & 8329366,0 & 0,0 & 913300,0 & 0,0 & 0,0 \\
\hline České štěrkopísky spol. s r.o. & 0,0 & 0,0 & 0,0 & 0,0 & 0,0 & 0,0 & 8391714,0 & 0,0 & 0,0 & 0,0 & 0,0 \\
\hline Českomoravský štěrk, a.s. & 0,0 & 0,0 & 0,0 & 0,0 & 0,0 & 14438435,0 & 6773798,0 & 0,0 & 0,0 & 0,0 & 0,0 \\
\hline EUROVIA Kamenolomy, a.s. & 0,0 & 0,0 & 0,0 & 0,0 & 0,0 & 14413000,0 & 1524138,0 & 0,0 & 0,0 & 0,0 & 0,0 \\
\hline KÁMEN Zbraslav, a.s. & 0,0 & 0,0 & 0,0 & 0,0 & 0,0 & 6826266,0 & 3116205,0 & 0,0 & 0,0 & 0,0 & 0,0 \\
\hline KAMENOLOMY ČR s.r.o. & 0,0 & 0,0 & 0,0 & 0,0 & 0,0 & 14559361,0 & 1317316,0 & 0,0 & 0,0 & 0,0 & 0,0 \\
\hline HELUZ cihlářský průmysl v.o.s. & 0,0 & 0,0 & 0,0 & 0,0 & 2345807,0 & 0,0 & 0,0 & 0,0 & 0,0 & 0,0 & 0,0 \\
\hline Wienerberger s.r.o. & 0,0 & 0,0 & 0,0 & 0,0 & 2546000,0 & 0,0 & 0,0 & 0,0 & 0,0 & 0,0 & 0,0 \\
\hline Cihelna Hodonín, s.r.o. & 0,0 & 0,0 & 0,0 & 0,0 & 275700,0 & 0,0 & 0,0 & 0,0 & 0,0 & 0,0 & 0,0 \\
\hline Severočeské doly a.s. & 0,0 & 154854,0 & 0,0 & 0,0 & 0,0 & 0,0 & 0,0 & 0,0 & 0,0 & 0,0 & 0,0 \\
\hline Sokolovská uhelná, právní nástupce, a.s. & 0,0 & 32367,0 & 0,0 & 0,0 & 0,0 & 215580,0 & 0,0 & 0,0 & 0,0 & 0,0 & 0,0 \\
\hline Vršanská uhelná a.s. & 0,0 & 52673,0 & 0,0 & 0,0 & 0,0 & 0,0 & 0,0 & 0,0 & 0,0 & 0,0 & 0,0 \\
\hline Severní energetická a.s. & 0,0 & 25152,0 & 0,0 & 0,0 & 0,0 & 0,0 & 0,0 & 0,0 & 0,0 & 0,0 & 0,0 \\
\hline Green Gas DPB, a.s. & 0,0 & 0,0 & 106,3 & 593,4 & 0,0 & 0,0 & 0,0 & 0,0 & 0,0 & 0,0 & 0,0 \\
\hline MND a.s. & 0,0 & 158,7 & 867,5 & 627,2 & 0,0 & 0,0 & 0,0 & 0,0 & 0,0 & 0,0 & 0,0 \\
\hline
\end{tabular}


Michal VANĚK et al. / Acta Montanistica Slovaca, Volume 26 (2021), Number 4, 732-747

\begin{tabular}{|c|c|c|c|c|c|c|c|c|c|c|c|}
\hline LAMA GAS \& OIL s.r.o. & 0,0 & 4,3 & 63,2 & 238,1 & 0,0 & 0,0 & 0,0 & 0,0 & 0,0 & 0,0 & 0,0 \\
\hline OKD, a.s. & 62994,0 & 0,0 & 0,0 & 0,0 & 0,0 & 0,0 & 0,0 & 0,0 & 0,0 & 0,0 & 0,0 \\
\hline Českomoravský cement, a.s. & 0,0 & 0,0 & 0,0 & 0,0 & 0,0 & 0,0 & 0,0 & 0,0 & 9241199,0 & 0,0 & 0,0 \\
\hline $\begin{array}{c}\text { Velkolom Čertovy schody, akciová } \\
\text { společnost }\end{array}$ & 0,0 & 0,0 & 0,0 & 0,0 & 0,0 & 0,0 & 0,0 & 0,0 & 14628943,0 & 0,0 & 0,0 \\
\hline KOTOUČ ŠTRAMBERK, spol. s r. o. & 0,0 & 0,0 & 0,0 & 0,0 & 0,0 & 0,0 & 0,0 & 0,0 & 6480500,0 & 0,0 & 0,0 \\
\hline Cement Hranice, akciová společnost & 0,0 & 0,0 & 0,0 & 0,0 & 0,0 & 0,0 & 0,0 & 0,0 & 10902754,0 & 0,0 & 0,0 \\
\hline
\end{tabular}

